\title{
Bonamia status and its effects in cultured flat oysters in the Ria de Vigo, Galicia (N.W. Spain)
}

\author{
A. J. Figueras \\ Instituto de Investigaciones Marinas CSIC, Vigo, Eduardo Cabello 6, 36208 Vigo, \\ Spain
}

\section{ABSTRACT}

Figueras, A.J., 1991. Bonamia status and its effects in cultured flat oysters in the Ria de Vigo, Galicia (N.W. Spain). Aquaculture, 93: 225-233.

Hatchery-reared spat obtained from native oyster stocks was cultured. The spat was placed in baskets on rafts at 12 months of age. Bimonthly samples were taken and the presence of Bonamia, other pathological conditions and mortality were estimated.

\section{INTRODUCTION}

Production of cultured flat oyster (Ostrea edulis) has suffered a dramatic decrease since 1974 due to the lack of oyster spat formerly supplied by French producers. This was the result of a crash in their culture attributed to Marteilia refringens (Masso, 1978). This parasite was introduced in the same way as Bonamia ostreae in the 1980s (Figueras, unpublished): with the spat for culture and with the adults that were imported for human consumption. This has contributed to the virtual disappearance of this species in culture in Galicia. At present the "production” of flat oyster (Ostrea edulis) is mainly an import business, with little or no production of native oysters. An interesting review of the status of Bonamia disease has been given by Grizel et al. (1988). Mortality attributed to a neoplastic disorder and reaching levels of $60-80 \%$ has also been described in flat oysters cultured in Galicia (Alderman et al., 1977).

In this paper the prevalence of Bonamia and other pathological conditions and their relationship with mortality rates are described. 


\section{MATERIAL AND METHODS}

Hatchery-reared spat obtained from oyster stocks at Vigo was cultured. The spat was placed in baskets on rafts in Domayo (Ria de Vigo, Fig. 1) at 12 months of age. From May 1988 to September 1989 approximately 25 to 30 oysters were collected bimonthly, and mortality was estimated by counting the number of dead and live oysters from a total of 1500 individuals. The sampled animals were fixed in order to prepare histological slides to detect the presence of pathogens. After shell removal all tissues were fixed in Davidson's fixative (Shaw and Battle, 1957). An anterior transverse section was taken including digestive gland, mantle, and gills. Histological sections were cut 5 pm thick and stained with iron haematoxylin, acid fuchsin and aniline blue (Gray, 1954).

\section{RESULTS}

\section{Pathological conditions}

The different pathological conditions detected were Bonamia sp., ciliates in gills, neoplastic cells, haemocyte infiltration (Alderman et al., 1977), and aggregates of granulocytes (granulocytoma).

At the beginning of the experiment the slightly basophilic types of Bonamia were more abundant. One year later, when mortalities were higher, the highly basophilic Bonamia types were more abundant. The "neoplastic cells” had pleomorphic or spheroid nuclei, and they were hypertrophied, usually enlarged to two to four times the diameters of normal haemocytes.

Only in one animal was Marteilia refringens detected in the digestive epithelium of the stomach, and in oocytes of a mature oyster the microsporidian Steinhausia ovicola was found.

There was no clear relationship between the prevalence of the different pathological conditions and the age of the animals (Fig. 2) . There was a notable decrease in the prevalence of Bonamia after 2 months on the raft. 
The presence of different pathological conditions in the same animal was also studied and is shown in Table 1. The animals that had Bonamia sp. tended also to show the presence of general haemocyte infiltration and the presence of granulocytomas.

In Table 2 the correlations between the prevalences of different pathological conditions and the mortality rates and mean length are shown.

\section{Mortality}

The mortality was relatively "low” until the oysters were 24 months old (May 1989) (Fig. 3). After that, it reached almost $40 \%$ in September. There was an intriguing decrease in mortality in July, between the higher mortality rates registered in May and September (1989).

There was no clear relation between the mortality rate and the pattern of growth in meat weight, length and total weight, although after the first peak in mortality there was a decrease in the mean total length, meat weight and total weight (Fig. 3). This could indicate that the bigger oysters die before the smaller ones. In a current experiment, mortality rates are being monitored taking into account the oysters with higher growth versus the slower growing individuals.

From Fig. 4 a and b, it would seem possible to culture oysters up to commercial size before great losses are experienced. After 14 months of culture more than $60 \%$ of commercial size oysters are obtained during the best commercial season in Spain (December).

The correlation between the different pathological conditions and the mortality during this period is shown in Fig. 5. It is significant for the first four conditions shown.

Comparison of the mortalities caused by Bonamia in 1984 (Montes and Melendez, 1987) and in 1988 (present study) with previous mortalities attributed to Marteilia refringens (Masso, 1978) shows that the virulence of Bonamia is higher (Fig. 6). Further studies will show if there is any trend in the decrease in mortality rates. 


\section{DISCUSSION}

Oyster growers from Vigo have confirmed that they introduced flat oyster spat from Bodega Bay (California) before the mortalities attributed to Marteilia refringens began in Galicia. Some authors believe that the origin of Bonamia is in that part of the United States (Elston et al., 1986).

One striking aspect of the histopathological data is the almost complete disappearance of Marteilia refringens which was the cause of the mortalities in cultured oysters in Galicia during the 1970s. Masso (1978) had already indicated the lack of correlation between the prevalences of Marteilia refringens and the mortalities found. This makes one wonder whether Marteilia was the true killer or whether some other, undescribed, factor was responsible.

The presence of the neoplastic cells is also intriguing. Alderman et al. (1977) had attributed a mortality that appeared in Galicia and Yugoslavia to the presence of this pathological condition. These authors described what they considered to be a disseminated sarcoma with a proliferation of atypical haemocytic cells that developed into a widespread degeneration and necrosis of tissues with death of the organism. They also were able to induce the disease in healthy oysters by placing them near "infected" animals in the field. On the other hand, Grizel and Hine (pers. commun.) consider the presence of the so-called "neoplastic cells" to be a consequence of infection rather than etiological. When the animal is dying because of Bonamia, the "neoplastic cells" appear. More research should be focused on this part of the Bonamia syndrome, to determine the importance of the appearance of the "neoplastic" cells and their relationship with Bonamia. The correlation of the frequency of appearance of ciliates and Bonamia could be explained by a high Bonamia infection corresponding to a prephase of mortality. The good correlation between the frequency of appearance of Bonamia and haemocytic infiltration is explained by the reaction of the cellular defence mechanisms to a non-self stimulus. The data also show that the pattern of the disease already described in different areas of the world (Grizel et al., 1988) is again maintained. There are no big differences between rias. 
It is also possible, as with other molluscan diseases, to "manage around" the disease; in other words, relatively high numbers of commercial size oysters can be obtained before the major peak of mortality occurs.

With the upcoming data on the performance of fast-growing versus slow-growing strains of flat oysters, more light may be shed on the cause of death of oysters with Bonamia. This increase in knowledge of the disease will result in better management of the culture of this economically important species.

\section{REFERENCES}

Alderman, D.J., Van Banning, P. and Perez Colomer, A., 1977. Two European oysters (Ostrea edulis) mortalities associated with an abnormal hemocytic condition. Aquaculture. 10: 340-355.

Elston, R., Farley, C. and Kent, M., 1986. Occurrence and significance of bonamiasis in European flat oyster Ostrea edulis in North America. Dis. Aquat. Organisms, 2: 4954.

Gray, P., 1954. The Microtomist’s Formulary and Guide. Blakiston, New York, NY, 749 pp.

Grizel, H., Mialhe, E., Chagot, D., Boulo, V. and Bachere, E., 1988. Bonamiasis: a mode1 study of diseases in marine molluscs. In: W.S. Fisher (Editor), Disease Processes in Marine Bivalve Molluscs. Am. Fish. Sot. Spec. Publ. No. 18, pp. 1-4. Masso, J.M., 1978. La enfermedad de la glandula digestive de la ostra (Ostrea edulis L.) en las rias bajas. Bol. Inst. Esp. Oceanogr., 4: 125- 140.

Montes, J. and Melendez. MI., 1987. Données sur la parasitose de Bonamia ostreue chez l'huitre plate de Galice, Cote nord-ouest de I’Espagne. Aquaculture, 67: 195198.

Shaw, B.L. and Battle, H.I., 1957. The gross and microscopic anatomy of the digestive tract of the oyster Crassostreu virginica (Gmelin). Can. J. Zool., 35: 325-346. 
Fig. 1. Sites sampled in the Rias Bajas (Galicia) from 1974 to 1989.

Fig. 2. Relation between age in months and the prevalences of pathological conditions and mortality rates.

Fig. 3. Relation between the age, mortality rate and the pattern of meat weight, length and total weight.

Fig. 4. Relation between age and the proportions of the different size (4a) and weight (4b) classes of marketable oysters.

Fig. 5. Regressions of the prevalences of diseases and parasites and the mortality rates.

Fig. 6. Comparison of the mortalities attributed to Bonamia in the 1980s with previous mortalities attributed to Marteilia refrringens

\section{TABLE I}

Correlation between the different pathological conditions appearing in the same animal: Spearman rank correlation

\section{TABLE 2}

Correlations between the prevalences of different pathological conditions and the monthly mortality rate and mean length: Pearson product-moment correlation 
Table 1

\begin{tabular}{llllllll}
\hline & SEX & INFILT. & GRAN. & BONAM. & CILIAT. & NEOPL. & AGE \\
\hline SEX & 1.000 & & & & & & \\
INFILT. & 0.186 & 1.000 & & & & & \\
GRAN. & 0.037 & 0.447 & 1.000 & & & & \\
BONAM. & 0.005 & $0.517^{*}$ & $0.440^{*}$ & 1.000 & & & \\
CILIAT. & 0.008 & 0.170 & 0.026 & 0.138 & 1.000 & & \\
NEOPL. & 0.200 & 0.231 & 0.199 & 0.248 & 0.112 & 1.000 & \\
AGE & 0.183 & 0.318 & 0.101 & 0.336 & 0.270 & 0.298 & 1.000 \\
\hline
\end{tabular}

*Significant correlation.

INFILT. = haemocytic infiltration; GRAN. = granuloma; BONAM. = Bonamia;

CILIAT. $=$ ciliates; NEOPL.$=$ neoplastic cells.

Table 2

$\begin{array}{lllllll}\% & \% & \% & \% & \% & \text { Mortality } & \text { Mean } \\ \text { Bonam. } & \text { Infiltr. } & \text { Ciliates } & \text { Neopl. } & \text { Granul. } & & \text { length }\end{array}$

\% Bonam. 1.000

\% Inliltr. $\quad 0.905 * \quad 1.000$

\% Ciliates $\quad 0.682 * \quad 0.786 * 1.000$

$\begin{array}{lllll}\% & \text { Neopl. } & 0.551 & 0.593 & 0.676 * \\ & 1.000\end{array}$

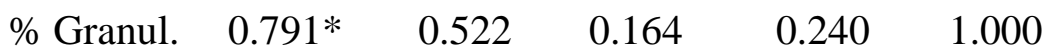

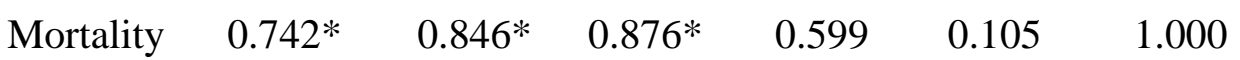

$\begin{array}{llllllll}\text { Mean } & 0.454 & 0.608 & 0.674 & 0.763^{*} & 0.361 & 0.276 & 1.000\end{array}$

length

*Significant correlation.

$\%$ Bonam. = prevalence of Bonamia; \% Infiltr. = prevalence of haemocytic infiltration;

$\%$ Ciliates = prevalence of ciliates; $\%$ Neopl. = prevalence of neoplastic cells; $\%$

Granul. = prevalence of granulocytoma; Mortality = mortality rate . 